\title{
MAPPING OF THE GENES AROUND MEN2A LOCUS USING PULSED-FIELD GEL ELECTROPHORESIS
}

\author{
Norifumi Tanaka, ${ }^{1}$ Tetsuro Mrki, ${ }^{2}$ Masayuki Yamamoto, ${ }^{1}$ \\ Jun Nakura, ${ }^{2}$ Makoto OKazakI ${ }^{1}$ Akihiro MiYa, ${ }^{1}$ \\ Takesada MORI, ${ }^{1}$ and Shin-ichiro TAKAI ${ }^{3}$ \\ ${ }^{1}$ Second Department of Surgery, ${ }^{2}$ Department of Geriatric Medicine and \\ ${ }^{3}$ Department of Medical Genetics of Biomedical Research Center, \\ Osaka University Medical School, Fukushima-ku, Osaka 553, Japan
}

Summary The gene for multiple endocrine neoplasia type 2A (MEN 2A) is closely linked to RBP3 (retinol-binding protein 3, interstitial, probe IRBP.H4) and the DNA marker D10S15 (probe pMCK2), which have been assigned to the proximal long arm of chromosome 10 by linkage analysis both in Caucasian and Japanese populations. We have constructed a rare-cutting restriction map around the RBP3 and D10S15 loci by pulsed-field gel electrophoresis (PFGE). The RBP3 and D10S15 loci appeared to be within a single $160 \mathrm{~kb} M l u \mathrm{I}$ fragment. In 5 patients with MEN 2A, gene rearrangements, such as a gross deletion, were not found in the $880 \mathrm{~kb} \mathrm{NruI}$ fragment which covered the closest region to the MEN2A locus from the RBP3 and D10S15 loci.

Key Words multiple endocrine neoplasia type 2A (MEN 2A), pulsedfield gel electrophoresis

\section{INTRODUCTION}

Multiple endocrine neoplasia type 2A (MEN 2A) is an autosomal dominant disease characterized by association of medullary thyroid carcinoma, pheochromocytoma and hyperplasia of parathyroid glands. The gene has been mapped to the pericentromeric region of chromosome 10 by the familial linkage studies between the MEN2A and the RBP3 (retinol-binding protein 3, interstitial) loci (Mathew et al., 1987; Simpson et al., 1987; Yamamoto et al., 1989).

Updated lod score data suggested very tight linkage between the MEN2A locus and the markers, IRBP.H4 (RBP3) and pMCK2 (D10S15): a maximum lod score $\left(Z_{\max }\right)=18.10$ at theta $=0.024$ for $R B P 3$ and $Z_{\max }=19.48$ at theta $=0.011$

Received June 27, 1990; Accepted November 13, 1990. 
for D10S15 (Nakamura et al., 1989), or $Z_{\max }-13.1$ at theta $=0.045$ for RBP3 and $Z_{\max }=17.3$ at theta $=0.054$ for D10S15 (Wu et al., 1990). Nakamura reported that there is no definite crossover between RBP3 and DIOS15 (Nakamura et al., 1989), while $\mathrm{Wu}$ observed two obligate crossovers between two loci (Wu et al., 1990). Although these three markers are linked together, it is difficult to estimate the accurate distance among them.

We therefore have constructed the rare-cutting restriction map in the MEN2A region using pulsed-field gel electrophoresis (PFGE) which is a powerful technique for analysis of large genomic regions.

\section{MATERIALS AND METHODS}

To prepare high molecular weight DNA for PFGE, lymphocytes isolated from fresh whole blood or lymphoblastoid cells transformed by Epstein-Barr virus are suspended in low melting point agarose (Smith et al., 1986). The blocks containing $3 \times 10^{6}$ cells per $100 \mu \mathrm{l}$ are treated for $48 \mathrm{hr}$ at $50^{\circ} \mathrm{C}$ with buffer of $0.5 \mathrm{M}$ EDTA and $2 \mathrm{mg} / \mathrm{ml}$ proteinase $\mathrm{K}$. After washing the blocks in $1 \times$ TE buffer (10 mM Tris, $1 \mathrm{~mm}$ EDTA), digestion by rare-cutting restriction enzymes was performed overnight. Then, the blocks were placed in a $1.0-1.5 \%$ agarose gel. The pulsedfield gel system used is a cross-field gel electrophoresis produced by ATTO Corporation (Tokyo). The system alternates the field by rotating the gel. To obtain optimal resolution of DNA fragments between 50 to $1,000 \mathrm{~kb}$, gels were run for 24-72 hr at 100-200 V, with a constant switching interval from 20 to $300 \mathrm{sec}$. After electrophoresis, the ethidium bromide-stained gels were exposed to short-wave UV light and treated with $0.25 \mathrm{M} \mathrm{HCl}$ (twice for $15 \mathrm{~min}$ ) (Maniatis et al., 1982). The DNA probes used were the cloned cDNA for RBP3 (retinol-binding protein 3, interstitial), IRBP.H4 (Liou et al., 1987), and an anonymous genomic clone pMCK2, which defines the D10S15 locus (Nakamura et al., 1988). The DNA probes were radioactively labeled by random priming to a specific activity of $10^{9}$ $\mathrm{dpm} / \mu \mathrm{g}$ (Feinberg and Vogelstein, 1983). The gels were denatured and transferred to nylon membranes (Hybond, Amersham) according to manufacturer's instructions and hybridized as previously described (Nishisho et al., 1986). After autoradiography, probes were removed from the filter by washing in $0.4 \mathrm{~N} \mathrm{NaOH}$ at $42^{\circ} \mathrm{C}$ for $30 \mathrm{~min}$ and in buffer containing $0.2 \mathrm{M}$ Tris- $\mathrm{HCl}, 0.1 \times \mathrm{SSC}$ and $0.5 \% \mathrm{SDS}$ for 30 $\min$.

\section{RESULTS}

The long-range restriction map for normal DNA samples was established using the restriction nucleases Not I, MhuI, NruI and SalI. Figure 1 shows the autoradiographs obtained after the same PFGE filter was hybridized with the RBP3 and DioS15 probes. In this filter, IRBP.H4 detected two NotI fragments of 400 


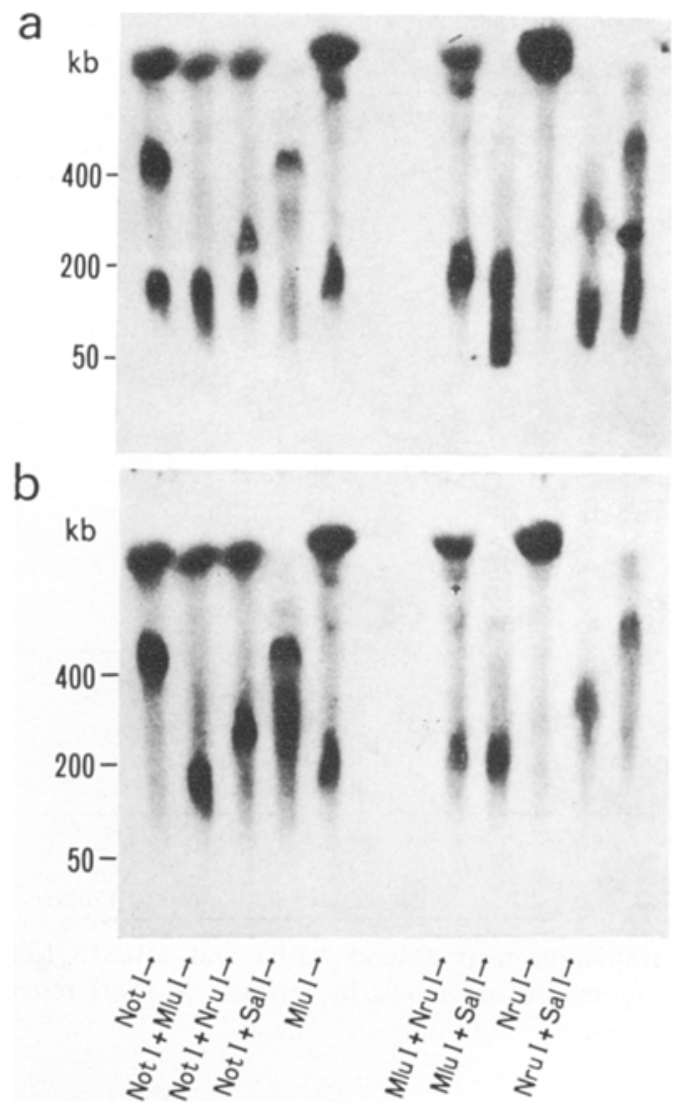

Fig. 1. PFGE analysis of human genomic DNA hybridized with IRBP.H4 (a) and subsequently with D10S15 (b). Digested enzymes were shown under the each lane. The sizes of DNA are shown on the left side of each autoradiograph. The 80 $\mathrm{kb} \mathrm{Not} \mathrm{I}+\operatorname{Sal} \mathrm{I}(\mathrm{a})$ and the $220 \mathrm{~kb}$ SalI fragment (b) were faint in this filter.

and $100 \mathrm{~kb}$, while pMCK2 detected two Not $\mathrm{I}$ fragments of 400 and $300 \mathrm{~kb}$. IRBP.H4 and pMCK2 showed the same $160 \mathrm{~kb} M l u I$ fragment. Moreover, both probes detected the same $880 \mathrm{~kb} \mathrm{NruI}$ fragment. IRBP.H4 detected a 80 $\mathrm{kb}$ SalI fragment, and pMCK2 a $220 \mathrm{~kb}$ Sall fragment, which was the faint band in this filter. More than one band of hybridization were detected in the cases of Not I, MluI, and SalI digestions. These fragments might have been produced by partial digestion, variable methylation, or restriction fragment length polymorphisms (RFLPs). Partial digestion was excluded by experiments in which decreasing the amount of enzymes gave rise to the same fragments. The fragments with the same size were observed in the unrelated individuals, so these fragments probably do not result from RFLPs. The most reasonable explanation is that variable methylation might cause these fragments. A summary of the smallest 
Table 1. Summary of restriction fragment sizes identified by IRBP.H4 and pMCK2. In all cases, the smallest fragments were shown.

\begin{tabular}{lcc} 
& IRBP.H4 & pMCK2 \\
\hline Not I & 100 & 300 \\
MluI & 160 & 160 \\
NruI & 880 & 880 \\
SalI & 80 & 220 \\
Not I + MluI & 80 & 80 \\
Not I + NruI & 100 & 240 \\
Not I + SalI & 70 & 180 \\
MluI + NruI & 160 & 160 \\
MluI + SalI & 50 & 120 \\
NruI + SalI & 80 & 220 \\
\hline
\end{tabular}

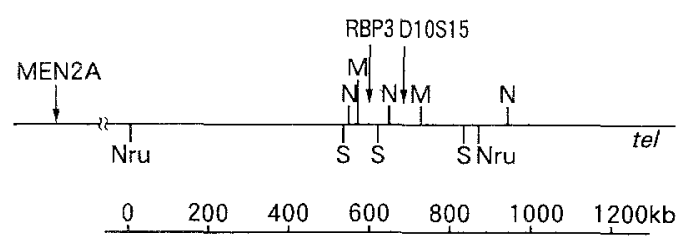

Fig. 2. Long-range restriction map around RBP3 and D10S15 loci. The positions of MEN2A and probe loci are shown by arrows. N, Not I restriction site; M, MluI; S, SalI; Nru, NruI.

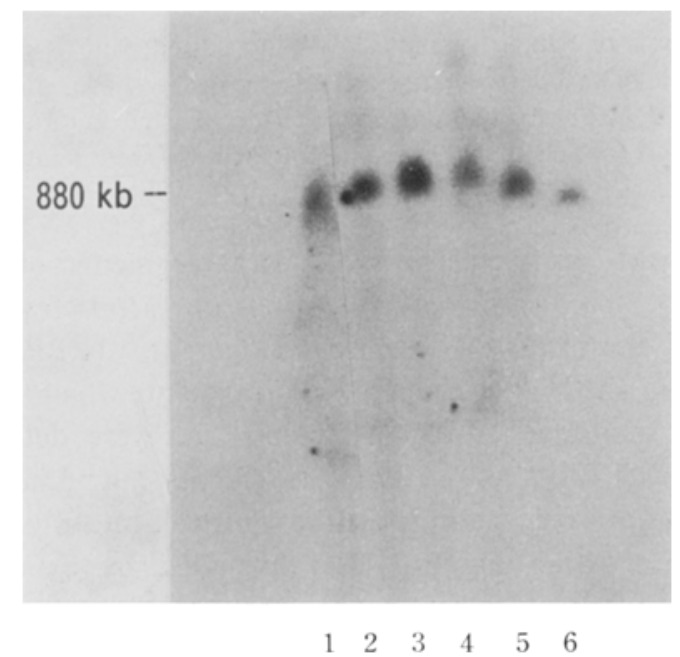

Fig. 3. PFGE analysis of MEN 2A patients. NruI-digested DNAs from the MEN 2A patients (lanes 2-6) and control (lane 1) were hybridized with the probe IRBP.H4. 
restriction fragments of single and double digestion of these enzymes is presented in Table 1. We have constructed a rare-cutting restriction map around the RBP3 and D10S15 loci (Fig. 2). Both the RBP3 and D10S15 loci are localized within a single $160 \mathrm{~kb} M l u \mathrm{I}$ fragment. Restriction sites for $\mathrm{Not} \mathrm{I}, \mathrm{Mlu \textrm {I }}$, and SalI cluster in a small region close to the RBP3 locus. The map orientation in Fig. 2 was deduced from the linkage data showing RBP3 is probably closer to MEN2A than is D10S15 (Wu et al., 1990). DNA samples from a normal individual and 5 patients with MEN 2A have been digested with NruI and hybridized with IRBP.H4, because the $880 \mathrm{~kb} \mathrm{NruI}$ fragment might cover the region closest to the MEN2A locus. However, all of them showed only one $880 \mathrm{~kb}$ band without altered bands (Fig. 3).

\section{DISCUSSION}

Once the linkage map around the gene for a genetic disease has been constructed, the next important step is to refine the physical map around this genetic locus and to analyze DNA from patients in order to find the genetic rearrangement in this region by the application of long-range restriction techniques, what is called PFGE. PFGE has proven very useful in the molecular genetic analysis of Duchenne muscular dystrophy and cystic fibrosis. Some patients with Duchenne muscular dystrophy or hemophilia A have shown deletion in the region of the responsible gene as shown by PFGE (Kunkel et al., 1986; Youssoufian et al., 1987). The physical map which we have made around the RBP3 and D10S15 loci by PFGE demonstrates that the molecular distance between RBP3 and D10S15 is within 160 $\mathrm{kb}$. This result is consistent with the familial linkage data which showed that there were no obligate recombinations observed between them (Nakamura et al., 1988 ) or only two recombination between them (Wu et al., 1990). The possibility that the MEN2A locus would be located within a few megabases from RBP3 and D10S15 encouraged us to analyze DNA from five patients with MEN 2A using the DNA probe RBP3 after digestion by $N r u \mathrm{I}$, because the $880 \mathrm{~kb} N r u \mathrm{I}$ fragment covered the region nearest to the MEN2A locus from the RBP3 and D10S15 loci. However, we could not detect any altered fragments that would have suggested a deletion or insertion in them. We are going to analyze DNA from other patients with MEN 2A and are trying to find other enzymes which cover a longer fragment extending toward MEN2A from the RBP3/D10S15 locus.

In this paper, we constructed the physical map only around the RBP3 locus, but in the near future, we will be able to construct a long range map containing the MEN2A locus by using new markers.

Acknowledgments We thank Dr. C.D.B. Bridges for providing the probe IRBP.H4 and also thanks Dr. Y. Nakamura for the probe pMCK2. We are grateful for Mrs. Y. Ebisui and Miss S. Fujita for technical assistance. We thank Professor K.K. Kidd and A.J. Pakstis for help in preparing the manuscript.

This work was supported by a Grant-in-Aid for Special Project Research, Cancer-Bioscience, from the Ministry of Education, Science and Culture of Japan. 


\section{REFERENCES}

Feinberg, A.P. and Vogelstein, B. 1983. A technique for radiolabeling DNA restriction endonuclease fragments to high specifie activity. Anal. Biochem. 132: 6-13.

Kunkel, L.M. and 75 coauthors. 1986. Analysis of deletions in DNA from patients with Becker and Duchenne muscular dystrophy. Nature 322: 73-77.

Liou, G.I., Li, Y., Wang, C., Fong, S.L., Battacharya, S. and Bridges, C.D.B. 1987. BglII RFLP recognised by a human IRBP cDNA localized to chromosome 10. Nucleic Acids Res. 15: 3196.

Maniatis, T., Frisch, E.F. and Sambrook, J. 1982. Molecular Cloning: A Laboratory Manual, Cold Spring Harbor Laboratory, Cold Spring Harbor, New York.

Mathew, C.G.P., Chin, K.S., Easton, D.F., Thorpe, K., Carter, C., Liou, G.I., Fong, S.-L., Bridges, C.D.B., Haak, H., Nieuwenhuijzen Kruseman, A.C., Schifter, S., Hansen, H.H., Telenius, H., Telenius-Berg, M.T. and Ponder, B.A.J. 1987. A linked genetic marker for multiple endocrine neoplasia type $2 \mathrm{~A}$ on chromosome 10 . Nature $328: 527-528$.

Nakamura, Y., Carlson, M., Krapcho, K., Gill, J., O'Connell, P., Leppert, M., Lathrop, M., Lalouel, J.-M. and White, R. 1988. Isolation and mapping of a polymorphic DNA sequence pMCK2 on chromosome 10 (D10S15). Nucleic Acids Res. 16: 374.

Nakamura, Y., Mathew, C.G.P., Sobol, H., Easton, D.F., Telenius, H., Bragg, T., Chin, K., Clark, J., Jones, C., Lenoir, G.M., White, R. and Ponder, B.A.J. 1989. Linked markers flanking the gene for multiple endocrine neoplasia type 2A. Genomics 5: 199-203.

Nishisho, I., Miki, T., Motomura, K., Nakura, J., Kumahara, Y., Mori, T. and Honjo, T. 1986. Isolation of DNA clones revealing restriction fragment length polymorphisms in human genome. Jpn. J. Human Genet. 31: 249-258.

Simpson, N.E., Kidd, K.K., Goodfellow, P.J., McDermid, H., Myers, S., Kidd, J.R., Jackson, C.E., Duncan, A.M.V., Farrer, L.A., Brasch, K., Castiglione, C., Genel, M., Garter, J., Greenberg, C.R., Gusella, J.F., Holden, J.J.A. and White, B.N. 1987. Assignment of multiple endocrine neoplasia type $2 \mathrm{~A}$ to chromosome 10 by linkage. Nature 328: $528-530$.

Smith, C.L., Warburbon, P.E., Gaal, A. and Cantor, C.R. 1986. Analysis of genome organization and rearrangements by pulsed field gradient gel electrophoresis. In Genetic Engineering, Vol. 8, Plenum Press, Newark, N.J., pp. 45-71.

Wu, J., Carson, N.L., Myers, S., Pakstis, A.J., Kidd, J.R., Castiglione, C.M., Anderson, L., Hoyle, L.S., Genel, M., Verdy, M., Jackson, C.E., Simpson, N.E. and Kidd, K.K. 1990. The genetic defect in multiple endocrine neoplasia type $2 \mathrm{~A}$ maps next to the centromere ef chromosome 10. Am. J. Hum, Genet. 46: 624-630.

Yamamoto, M., Takai, S., Miki, T., Motomura, K., Okazaki, M., Nishisho, I., Tateishi, H., Miyauchi, A., Honjo, T., Pakstis, A.J. and Mori, T. 1989. Close linkage of MEN2A with RBP3 locus in Japanese kindreds, Hum. Genet. 82: 287-288.

Youssoufian, H., Antonarakis, S., Aronis, S., Tsiftis, G., Phillips, D. and Kazazian, H.H., Jr. 1987. Characterization of five partial deletions of the factor VIII gene. Proc. Natl. Acad. Sci. U.S.A. 84: $3772-3776$. 